\title{
Utilization Of Electronic Mail And Teaching Effectiveness of English Language Teachers' In Secondary Schools In Abak Local Government Area, Akwa Ibom State-Nigeria
}

\author{
Iniobong Bassey Ema \\ Dept. Of Educational Technology and Library Science \\ University Of Uyo-Nigeria \\ Paulinus J. Etim (Ph. D) \\ Dept. Of Educational Technology and Library Science \\ University Of Uyo-Nigeria
}

\begin{abstract}
The advents of internet and Globalization have brought diversified activities in all aspects of human endeavour including the classroom. The introduction of instructional technologies in the classroom has caused a lot of researches in generating innovative pedagogical strategies to improve classroom communication. This study was therefore on utilization of electronic mail and Teaching effectiveness of English Language Teachers in secondary schools in Abak Local Government Area of Akwa Ibom State Nigeria. Technology Acceptance model and Diffusion of innovative theories were also used as a foundation for the study. This study adopted the descriptive survey design. Two hypotheses were raised to direct the study. There are $\mathbf{7 6}$ graduate English teachers in the 15 public secondary schools in Abak Local Government Area. Simple random sampling technique of hat and draw method was used to select 68 English Language teachers for the study. Researchers developed instrument tagged "Teachers Utilization of e-mail and Teaching Effectiveness Questionnaire (TUETEQ) was used to elicit information from the respondents. The instrument was face, content and criterion validated by two experts all in the Faculty of Education, University of Uyo, Uyo. Split half strategy was done using 12 English Language Teachers in the study area that were not used for the main study. Pearson Product Moment Correlation Co-efficient analysis was used to get the r-value. This value was further treated to Spearman Brown Prophetic formular to get reliability co-efficient of .83 . The questionnaire copies were administered to the respondents by the researchers and the copies were collected on the spot after completion. Their responses were coded and used for analysis using ttest statistics. Results of the analysis showed a significant influence of use of e-mail and teachers attitude on teaching effectiveness of English Language. Recommendations were made to improve the teaching of English Language to include among others that teachers of English Language should adopt the use of e-mail as innovative instructional strategy and that teachers should be trained to become computer literates for easy access to e-mail and thus promoting effectiveness of teaching.
\end{abstract}

Key words: Use of electronic mail, English Language, Teachers Teaching Effectiveness

\section{INTRODUCTION}

With the spread and development of science and technology around the world, electronic mail is fast becoming a way of life and applied in all aspects of human endeavour including teaching and learning. English is used as the major language of communication and enjoys a high prestige in schools and has increased rapidly since 1960. At present, the role and status of English is that it is the language of social context, political, sociocultural, business, education, 
industries, media, library, communication across borders and key subject in curriculum and language of imparting education". It is also a crucial determinant for University entrance and processing well-paid jobs in the commercial sector (Cheng, 2003). The different modification in English Language has led to presentation of facts and ideas in a diversified manner and also determines the effectiveness of the teaching process. Use of resource materials in the form of films, radio, TV has been there for a long time but there are innovative technologies that have proved successful in replacing this traditional system of teaching (Baki, 2010).

The traditional expository method of teaching English language has been drastically changed with the remarkable entry of technology. Technology provides the options of making teaching interesting and more productive in terms of performance. Technology is one of the most significant drivers of both social and linguistic change (Blake, 2000). Graddol (1997) stated that "technology lies at the art of globalization process; affecting Education, work and culture. As the used of English language has increased in popularity so as the need for technological qualified teachers to instruct students in the language.

It is true that there are teachers who use 'cutting edge' technology, but the majority of teachers still teach in the traditional strategies. The new era assigns new challenges and duties on the modern teacher and the researcher. None of these traditional methods are bad or damaging to the students. In fact, till date they are proving to be useful also. However, there are many more opportunities for students to gain confidence, practice and extend themselves to new innovations. With the rapid development of science and technology, the emerging of electronic mail and its application to teaching come into full play in English instruction and sets a favourable platform for reform and exploration on English teaching model in the new era (Albirini, 2006). A nation is at very high risk if she neglects or ignores technological developments. The growth of the nation will be slowed down and will never be able to catch up other developing nations. The language of communication is English Language and for this reason, it is important for English language teachers to be aware of the latest equipment and systems and to have full knowledge of what is available in any given situation (Dang and Nhung, 2014).

Mark (1995) defined electronic mail as a way to exchange information where messages can be sent from a personal computer or terminal to another via modem and telecommunication systems. The use of electronic mail as a communication tool for academic and personnel relationship started since 1970 . Electronic mail is an electronic means which enables a fast communication between sender and receiver (Brownlee-Conyers, 1996). Electronic mail is one of the Information and Communication Technologies (ICTs) that can be used in the teaching and learning process (Guofeng, 2010). The computer is the main medium in applying the electronic mail in the teaching and learning process. Electronic mail is quite useful to develop the abilities of listening, reading and writing (Dwyer, 1996). Electronic mail can play a more important role in developing reading ability. In many schools, it is impossible for teachers to hand out as many reading materials as possible to the students because of high enrolment and lack of funds, which limits the improvement of the students' reading ability. E-mail is definitely a good answer to this problem. The teacher is able to download as many materials as possible or scan important text and send it via mail to the students and even from students to students (McGrath, 2000). The advantages of e-mail use for teachers include: access to professional development; the opportunity to contact colleagues and share information and practice; opportunity to interact and share experiences, concepts and ideas with students and the ability to forge links that benefit the school (Ictadvice, 2003). 
According to Ken and Jason (2004), theoretical advantage of e-mail is that it widens the community of learners. This means that it can connect many learners and teachers at the same time. Learners can send and receive messages at their convenience. Research done by Brown (2008) showed that by using e-mails, teachers' can help students become better problem solvers and better communicators. This advantage will help the students to handle problem faced in their daily life. However, the use of electronic mail also has some disadvantages. According to Isleem (2003), one of the disadvantages of e-mail is that the receiver of the message sent cannot see the sender of the messages and this makes it difficult for the receiver to understand the sender emotions such as anger, sadness and happiness. Thus, it may be difficult to understand what the writer or the sender of the message means.

Teaching effectiveness is the efficient means of classroom communications so that students can understands the concepts and ideas put across by their teachers. The result of research conducted on teacher's use of e-mail by Mark (1995) showed that the students whose teachers taught via the electronic mail not only consulted with their teachers freely and thoroughly but often became better at communication. Many students always hesitate to ask questions when they are face to face with teachers, but they became bold and frank to ask without any worry via e-mail (Mark, 2000). On English teachers' attitude towards the utilization of e-mail to teach, Huang (2003) found out that teachers had positive attitudes toward computer technology and use of e-mail both in their daily lives and in language instruction. In educational settings like the classrooms, teacher's attitudes play a significant role in the attainment of educational goals. In another study by Mcalister, Dunn and Quinn (2005), teachers showed positive attitudes towards the use of e-mail, despite the fact that they did not have enough experience about technology utilization. English language students in schools have problems in acquiring writing skills such as grammatical writing problems, stylistic writing problems, word-use writing problems and some mechanical problems. These might be due to the strategies used in teaching English Language.

It is generally observed that class participation is an awkward and terrifying experience for most students as they find it difficult to understand English Language concepts. Students therefore become frustrated. It appears many questions about English Language learning from students more often cannot be answered during the regular classroom teaching because teachers and students seldomly have face-to-face communication after class due to the lack of time and lack of confidence in their teachers and also due to shyness. This insufficiency in communication has a negative influence and ruins the enthusiasm of both the teachers and the students to teach and study English Language. In such a case, the employment of e-mail might be good solution to this problem. It is not known if use of e-mail can enhance teachers' effectiveness in teaching this important subject. It is against this background of improving the teaching effectiveness of English Language teachers, that this research on Utilization of e-mail and teaching effectiveness of English teachers in secondary schools in Abak Local Government Area-Nigeria is investigated.

\section{RESEARCH METHODS}

This study is based on two theories namely; the theories of Diffusion of Innovations and Technology Acceptance Model". Roggers (1995) provided a theory named "Diffusion of Innovations theory" with five stages that analyses the characteristics of adopters of new innovation. These stages are; knowledge, persuasion, decision, implementation and confirmation. He asserted that the process through which an individual accepts an innovation passes from the first knowledge of an innovation, to forming an attitude towards the innovation, to a decision to adopt or reject, to implement the new idea, and confirmation of this 
decision. The theory emphasized the importance of attitudes toward innovation process and user acceptance rate in different stages.

Teachers' attitude to the use of electronic mail as learning tool in classroom teaching depends on the extent to which prospective teachers' use the computers to have access to e-mail. Different studies have shown that the successful implementation of educational technologies depends largely on the attitudes of teachers who are the implementing agents in classroom practice (Albirini, 2006). Teachers' computer knowledge, literacy and ability are the key factors for adopting it as a teaching tool.

The Technology Acceptance Model (TAM) as propounded by Davis (1989) is used for technology acceptance. The goal of TAM is "to provide an explanation on the determinants of computer acceptance that is general, capable of explaining user behaviour across a broad range of end-user competing technologies and user populations, while at the same time being both parsimonious and theoretically justified". This model also aimed at developing improved measures for system quality and focused on two theoretical constructs of perceived usefulness and perceived ease of use. Mostly, TAM explained the determinants of computer acceptance. The model also suggests that when users are presented with a new software package, a number of factors influence their decision about how and when they will use it. These theories are highly related to this study because innovation becomes imperative for improvement of teaching effectiveness and performance by students. This innovation with mediated instruction can help in effective and efficient classroom communication.

This study adopts survey research design. This design enabled the opportunity of measuring the current attitude or practices of the teachers. Two hypotheses were postulated to direct the study. The area of the study was Abak Local Government Area. It lies on the south-west of Akwa Ibom State. Bounded in the North by Ikono Local Government Area, North-west by Essien-Udim local government area, West by Etim Ekpo and Ukanufun local government area, in the South by Oruk- anam and in the East by Uyo local government area. Abak town is the local government headquarters and is located about 18 kilometres from Uyo, the state capital. It has a landmass of 304 square kilometres. The local government has 15 public secondary schools with 76 graduate English teachers. The local government has a reasonable level of internet connectivity. The simple random sampling technique of hat and draw was used to select 68 English teachers for the study. The primary instrument used in collecting data was the Teachers' Utilization of e-mail and Teaching Effectiveness Questionnaire (TUETEQ). The response categories were Strongly Agree (SA), Agree (A), Disagree (D) and Strongly Disagree (SD). The instrument was face, criterion and content validated by experts in Educational Technology and Educational Foundations, Measurement and Evaluation unit in the University of Uyo. Corrections were effected as suggested in the final form of the instrument used for the study.

The researcher conducted a test and used the Split-half strategy for reliability test on 12 English Language teachers in the study area. Pearson Product Moment Correlation co-efficient was used for the analysis and the result was treated to Spearman Brown Prophetic formula which yielded reliability co-efficient of .86. The instrument was therefore regarded as being reliable for use in the study. The questionnaire was personally administered to the respondents by the researchers and was collected on the spot after completion. Their responses were coded and used for analysis. 


\section{Hypothesis 1}

\section{DATA ANALYSIS AND DISCUSSION OF FINDINGS}

The use of e-mail does not significantly influence teaching effectiveness of English Language teachers.

The data were analysed using t-test statistics as seen in table 1

Table: 1 t-test analysis on the use of e-mail and teaching effectiveness of English Language teachers.

\begin{tabular}{|lccccccr|}
\hline Variables & N & $\overline{\boldsymbol{X}}$ & SD & df & t-cal & t-crit & Decision \\
\hline Use of E-mail & 34 & 29.90 & 5.20 & & & & \\
\hline & & & & 66 & $7.47^{*}$ & 1.98 & significant \\
\hline Teaching effectiveness & 34 & 34.46 & 3.98 & & & & \\
\hline @ $\mathrm{P}=<.05$ & & & & & & & \\
\hline
\end{tabular}

Table 1 shows that the calculated t-value of 7.47 is greater than the critical t-value of 1.98 at .05 level of significance with 66 degree of freedom. The result is significant; therefore the null hypothesis is rejected. The result means that the use of e-mail by English Language teachers significantly influenced their teaching effectiveness.

\section{Hypothesis 2}

Teacher's attitude towards the use of Electronic-mail does not significantly influence teachers teaching effectiveness in English Language.

The data were analysed using t-test statistics as seen in table 2

Table 1: t-test analysis on teachers' attitude and use of e-mail

\begin{tabular}{|lccccccr|}
\hline Variables & $\mathbf{N}$ & $\overline{\boldsymbol{X}}$ & $\mathbf{S D}$ & $\mathbf{d f}$ & t-cal & t-crit & Decision \\
\hline Teachers attitude & 34 & 27.02 & 5.47 & & & & \\
\hline & & & & 66 & $10.83^{*}$ & 1.98 & significant \\
\hline Use of e-mail & 34 & 34.41 & 3.45 & & & & \\
\hline @ $\mathrm{P}=<.05$ & & & & & & \\
\hline
\end{tabular}

The result in Table 2 shows that the calculated t-value of 10.83 is greater than the critical tvalue of 1.98 at .05 level of significance with 66 degree of freedom. The result is significant and therefore the null hypothesis is rejected. This means that teachers' attitude towards the use of e-mail significantly influence their teaching effectiveness of English Language.

\section{Teachers Effectiveness with the Use of Electronic-mail}

\section{DISCUSSION OF FINDINGS}

The result of the analysis shows a significant influence of use of e-mail and teaching effectiveness of teachers. The reason is that use of e-mail will expose the teachers to interact with their learners with interest and motivation in time and in space. This is in support of the views of Van and Corl (1998) and Blake (2000), that when e-mail communication is kept within one class, the teacher can easily connect communicative tasks to the topic currently being covered in class and thereby extending the learners' communicative time and involvement with that topic and also that technology is the most significant driver of interest and linguistic change. Instructors can design e-mail assignments as pre-class, post-class or 
supplementary activities. The result is also in line with the findings of Jou (2008) whose results provided evidence for the positive effectiveness of Mobile-based e-mail in writing comprehension.

\section{Teachers' Attitude towards the use of electronic-mail}

The findings also indicate that teacher's attitude towards the use of electronic mail significantly influence their teaching effectiveness of English Language. The reason for this result is that when teachers are ICT literate, their attitudes towards the use of ICT tools will improve. This finding is in line with the study of Albirini (2004) and Isleem (2003) whose findings indicated that there is a significant relationship between teachers' attitudes towards e-mail and the actual level of e-mail use. This indicates that some teachers hold negative attitudes towards the use of e-mail and as a result, they are less likely to contribute effectively while others with positive attitude will frequently use this technology.

\section{CONCLUSION}

E-mail is very helpful for efficient and effective teachers to improve their own teaching strategies. English Language teachers can share teaching experience, ideas, methodology, materials by communicating with their counterparts and students from other schools and universities both at home and abroad via e-mail to break the limits and to improve their English teaching and learning. Undoubtedly, the biggest change brought about by online education is that the cooperation between teachers and students is strengthened more and more (Mark, 2000). We can draw a conclusion from the above analysis that students' initiatives and interests will be greatly aroused if the teachers make good use of e-mail technology in their teaching. But it has to be acknowledged that nothing can take the place of teachers in the teaching activities. Teachers should catch up with the development of the technology by acquiring the modern innovative strategies so that they can help the students benefit as much as possible from the use of e-mail.

\section{RECOMMENDATIONS}

On the basis of the findings mentioned above, the researchers offer the following recommendations:

1) English teachers should adopt electronic-mail as part of their instructional strategy for improving themselves and students' academic performance.

2) Teachers in rural areas should be trained on the importance of technology so that positive attitudes towards science and technology can be built in them.

3) Families should endeavour to possess a personal computer connected to the internet so that the teaching and learning process through the use of electronic mails can be possible when their wards use e-mail packages.

4) Government should provide teachers with personal computers and aids to which they can access the internet even from their homes.

5) Teachers should be trained to be computer literate for easy access to the computer and e-mails messages.

\section{References}

Albirini, A. (2006). Teachers' attitudes towards Information and Communication Technologies: the case of Syrian EFL teachers. Journal of Computer and education, 47 (4) pp. 373-398.

Baki, E. (2010). A Comparison of undergraduate students' English Vocabulary Learning: Using Mobile Phones and Flash cards. TOJET: The Turkish Online Journal of Educational Technology. 9 (3).

Blake, R. (2000). Computer mediated communication: a window on 12 Spanish inter-languages. Journal of Language Learning and Technology, 4 (1), 120-136. 
Ema, I. B., Etim, P. J. (2017). Utilization Of Electronic Mail And Teaching Effectiveness Of English Language Teachers' In Secondary Schools In Abak Local Government Area, Akwa Ibom State-Nigeria. Advances in Social Sciences Research Journal, 4(10) 26-32.

Brown, L. (2008). Using Mobile Learning to teach Reading to Ninth-Grade students. Capella University. Published Dissertation.

Brownlee-Conyers, J. (1996). Voices from Networked Classrooms. Journal of Educational Leadership, 54 (3), 34-37.

Cheng, Y. (2003). Effect of Web-based Instruction on Chinese EFL students' Learning Outcomes. Journal of Computer and Education, 64 (2) 382-410.

Dang, H. T., and Nhung, H. T. (2014). An Exploratory Study of ICT Use in English Language Learning among EFL University Students. Teaching English Language with Technology, 14 (4), 32-46 retrieved from http://www.tewjournal.org

Davis F. D. (1989). Perceived Usefulness, Perceived Ease of Use and User Acceptance of Technology. MIS Quarterly, 1989, 13 (3) 319-341.

Dwyer, D. (1996). A response to Douglas Noble: We're in this together. Journal of Educational Leadership, 54 (3), 24-27.

Graddol, D. (1997). Investigating the Use of the E-mail in the Teaching and Learning of a Technical subject among Polytechnic students in Ungku Omar. Chen Mei Ching: the future of English.

Guofeng, W. (2010). The Application of E-mail to College English Teaching in China. Foreign Languages Department, Shandong Institute of Business and Technology.

Huang, S. (2003). The Attitudes Towards Adopting Information Technology by Vocational and Technological Teachers in Southern Taiwan (China). Doctoral Dissertation, Idaho State University (2003). ProQuest Digital Dissertations (UMI No. AAT 3082993).

Ictadvice (2003). What are the Management Issues of Teachers' Access to Web and E-mail? http://schools.becta.org.uk. Retrieved $3^{\text {rd }}$ April, 2016.

Isleem, M. B. (2003). Relationship of selected factors and the level of Computer Use for Instructional Purposes by Technology Education Teachers in Ohio Public Schools: A state-wide survey. Unpublished Ph. D Thesis in Ohio University.

Jou, Y. (2008). The Effect of e-mail Keypal Project on the Enhancement of Reading and Writing Performance of Elementary School-Aged Efl students in Taiwan. Published Dissertation: Alliant International University. San Diego.

Ken, W. W. and Jason, D. B. (2004). The Students Guide to Successful Online Learning. Boston: Pearson Education Inc.

Mark, W. (1995). E-mail for English teaching. Washington DC:TESOL.

Mark, G. (2000). Integrating the Internet for Meaningful Learning. New York: Houghton Mifflin Company.

Mcalister, M., Dunn, J., and Quinn, L. (2005). Student teachers'attitudes to and use of computers to teach Mathematics in the primary classroom. Technology, Pedagogy and Education, 14 (1), 77-77-106.

McGrath, B. (1998). 'Partners in Learning: Twelve ways technology changes the teacher-student Relationship', Technological Horizon in Education, 25 (9), 58-62.

Rogers, E. M. (1995). Diffusion of Innovations. (4th ed.). The Free Press. New York.

Van Handle, D. C., and Corl, K. A. (1998). Extending the dialogue: Using electronic mail and the internet to promote conversation and writing in intermediate level German Language courses. CALICO Journal 15 (1-3), 129-143. 